Monika Paś (D) National Museum in Krakow mpas@mnk.pl

\title{
Spanish Style Walking Sticks in the Collection of the National Museum in Krakow
}

\begin{abstract}
The collection of the National Museum in Krakow includes over ninety walking sticks from different parts of Europe, Asia and Africa, dated from the $18^{\text {th }}$ century to the second half of the $20^{\text {th }}$ century. Most are kept in the Department of Decorative Arts, Material Culture and Militaria, in the collection of which artefacts manufactured in Spain constitute a relatively small percent. Therefore, from this group it is worth presenting two walking sticks, previously unpublished, connected with the culture and art of the Iberian peninsula. The staffs described in this article represent two categories. The first of them is an elegant clothing accessory carried by a man who took care of his appearance. A note in the documentation of the donation indicates the cane had once belonged to Lucjan Siemieński (1807-1877), a Polish poet. Although its handle was made in Eibar or Toledo, as a whole the cane might have been made and used outside Spanish borders. Regardless of the how and where the cane was bought by Siemieński, it seems it can be dated to the third quarter of the $19^{\text {th }}$ century. The second of the staffs, linked more with the local folklore, provides information about the place where it was made. The inscription visible on the bottom ferrule suggests the staff was made in 1881 in Saint-Jean de-Luz, a town on the Atlantic coast in the NouvelleAquitaine region, France, several kilometres from the border with Spain, a part of the Basque province of Labourd (Lapurdi). Both the construction and decoration signify that is a makila (makhila), a cane characteristic of the Basque men's costume.
\end{abstract}

Keywords: walking sticks, Toledo, makila, Basques, National Museum in Krakow 
Apart from its basic, purely utilitarian functions - as an aid and a weapon - and symbolic ones as a symbol of power and office, a walking stick served for quite a long time as a fashionable accessory of attire. ${ }^{1}$ In Polish scientific and popular literature, there are no studies on the history or typology of this object to be found. Brief dictionary and encyclopaedia entries do not devote much attention to walking canes, as they focus on the description of this artefact as a symbol of power, rank and office (Orgelbrand, 1864: 717; Gloger, 1902: 135-137, Wielka Encyklopedyja, 1908: 977; Brückner, 1939: 758-760). Information provided by studies in the field of the history of garments is equally general (Gutkowska-Rychlewska, 1968). In short, it can be said that a walking stick used as a trendy accessory appeared for the first time in women's fashion in France as early as in the $11^{\text {th }}$ century, to become popular for a short time in the late $15^{\text {th }}$ century, and then back into fashion towards the end of the $18^{\text {th }}$ century. It was present in men's fashion from the first half of the $16^{\text {th }}$ century: King Henry VII of England (1491-1547) had a few staffs in his collection; in the first quarter of the $17^{\text {th }}$ century the stick became an indispensable accessory of elegant attire and remained in use until around the mid$20^{\text {th }}$ century (Morris Lester, Oerke, 1940: 388-401). Canes were, like snuffboxes, at the peak of their popularity an element of accessory sets, made uniform in terms of materials and decorative motifs. Over such a long period walking sticks changed, as did all utilitarian articles, depending on the fashion of the day, which to some extent standardised their shape. This concerns above all canes used by the upper classes, and not so much those connected with regional folklore. This is exemplified by walking sticks with an S-shaped porcelain handle with the representation of a woman's head with a collar (Fr. à la collerette), made in the $18^{\text {th }}$ and $19^{\text {th }}$ centuries in Meissen and Berlin factories (Dike, Bezzaz, 1988: 177-179, 187-190). A staff with the handle of this type belonged to the family of the Mayor of London (Boothroyd,

${ }^{1}$ The article has been written as part of a scientific project whose aim is to write a study on the collection of walking sticks at the National Museum in Krakow. 
1973: 112) ${ }^{2}$ and one was given to Karol Fryderyk Woyda (1771-1846), Mayor of Warsaw, from Julian Ursyn Niemcewicz (1758-1841), a Polish writer and historian, on 10 September 1818 (Bobrow, 2008: 211). ${ }^{3}$ Preserved examples of canes with handles of this type can be found in the holdings of different European Museums. ${ }^{4}$ Nevertheless, one can observe considerable diversity resulting from materials and decorative techniques used locally, thanks to which it is sometimes possible, although not always precisely and without doubt, to indicate the place of their origin.

The collection of the National Museum in Krakow includes over ninety walking sticks from different parts of Europe, Asia and Africa, dated from the $18^{\text {th }}$ century to the second half of the $20^{\text {th }}$ century. Most are kept in the Department of Decorative Arts, Material Culture and Militaria, in the collection of which artefacts manufactured in Spain constitute a relatively small percentage. ${ }^{5}$ These are examples of ceramics, fragments of textiles and single articles of clothing, specimens of cold steel and firearms, and other objects which do not make up larger, homogenous thematic groups. Therefore, it is worth presenting, from this diverse but quite random group, two walking sticks, previously unpublished, connected with the culture and art of the Iberian Peninsula.

The first of them is a staff, $87.5 \mathrm{~cm}$ long, with a plain, smooth, relatively thin shaft tapering slightly towards the bottom, of ebony wood or wood varnished black, with a handle in the shape of a ball-shaped

${ }^{2}$ Unfortunately the author does not specify which particular mayor is concerned.

${ }^{3}$ Currently the handle is in the collection of the National Museum in Warsaw, inv. no. $42422 \mathrm{MNW}$.

${ }^{4}$ Apart from the mentioned object, notable is a staff with a handle of this kind in the holdings of the National Museum in Krakow - inv. no. MNK IV-C-1963; several handles are part of the collection of the Zeeuws Museum, The Netherlands - inv. no. AB 1040-1043; a similar one is in the collection of the British Royal Family: Royal Collection Trust, RCIN 31821.

${ }^{5}$ It should be noted the collection is not complete. Attempts are made to add to it through gifts and purchases. 


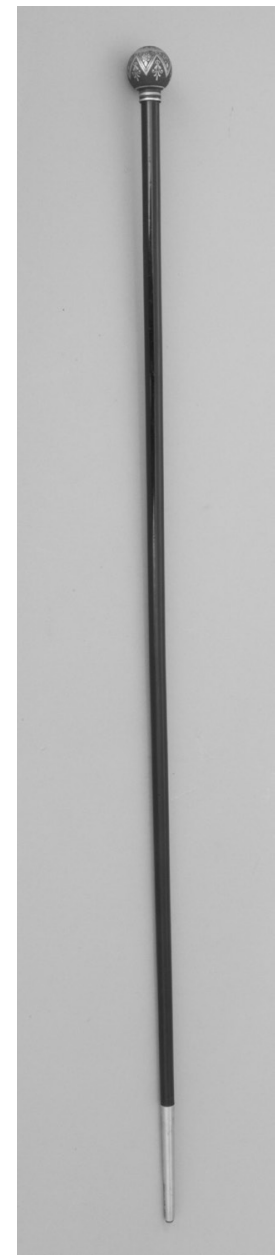

Fig. 1. Walking cane, Spain, Eibar or Toledo, $3^{\text {rd }}$ quarter of the $19^{\text {th }}$ century knob with a diameter of $3.0 \mathrm{~cm}$, cast in matt black iron and encrusted with gold, geometric plant motifs. The Moorish details are additionally decorated with delicate punching. The bottom end of the staff is finished with a ferrule in the shape of a cornet made from sheet copper [Fig. 1]. ${ }^{6}$

What is worthy of note is the type of encrustation called inlaying (taushiya in Arabic), which consists in decorating the surface of metal - usually iron - objects with an ornament of silver or gold thread. The place where the decorative metal is to be applied is gently cut and etched with acid to obtain a rough surface, like on a file. Then flakes of another metal are applied to the surface and forced into the recesses of the surface with a hammer. Gold or silver set in this way sticks to porous spots and stays on the surface of the decorated artefact in the form of a durable, smooth pattern (Siedlecka, 1964: 10-11; Zwolińska, Malicki, 1975: 233; Słownik terminologiczny, 1997: 83). This technique was known as early as in antiquity (mainly in Asia and Africa), and in the Middle Ages it developed in Islamic countries, where it was used primarily to embellish sidearms and armour. The leading manufacturing and trade centre for objects

6 The National Museum in Krakow, inventory number MNK IV-MO-1071; gift of Stanisław Ursyn-Rusiecki, 1935-1937. 
decorated in this way was Damascus, which exported the finest pieces of craftsmanship. Hence the popular name of this technique - damascening. Trade exchange brought damascening to Spain in the Early Middle Ages, where it reached mastery, and then it was taken to other European countries.

Both the technique of manufacturing and the characteristically arranged Moorish decorative motifs suggest this object was made in Spain. Handles of staffs and umbrellas embellished in this way - usually spherical and bent in the shape of the letter "l" or a turned "u", although there are other shapes - were in the $19^{\text {th }}$ century produced in Eibar (in the province of Guipúzcoa of the Basque Country) and Toledo (Lavin, 1997: 124, 167, 168, 169; Bujanovics, 2011: 156-159). It is worth noting that the revival and peak development of the art of damascening was linked with the work of Eusebio Zuloaga (1808-1898), a descendant of a Basque family of gunsmiths and armourers with tradition going back to the end of the $16^{\text {th }}$ century, and his son Plácido Zuloaga (1834-1910). They both received numerous awards and distinctions for their works decorated in this technique at world exhibitions, gaining international renown. Plácido Zuloaga improved this method, and apart from decorating weapons he used damascening to embellish a variety of other objects: clocks, caskets, vases, inkstands, and larger architectural works. These extremely stunning objects, not for everyday use, were so intricate that they were probably worked on by a team of craftsmen, representing different fields, under Zuloaga's supervision. Most of the pieces made in his workshop were commissioned by the English collector Alfred Morrison (1821-1897), an heir to a large fortune, whom Plácido Zuloaga probably had met personally in 1862 at an exhibition in South Kensington (Lavin, 1997: 54) 7 . Plácido Zuloaga educated many disciples who later opened their own workshops (Lavin, 1997: 65). Probably at the same time as Euzebio Zuloaga was practising this technique of damascening, it was also

${ }^{7}$ Many of them are now in the collection amassed by the British-Iranian collector Nassir Khalili, see https://en.wikipedia.org/wiki/Khalili_ Collection_of_Spanish_Metalwork. 
done in Toledo, where the Royal Sword Factory of Toledo (Real Fábrica de Espadas de Toledo), established by King Charles III, operated from 1761, but the quality was not as high as that in Eibar (Lavin, 1997: 185). In 1865-1875, damascened elements were imported from Eibar and assembled in the Toledo factory. ${ }^{8}$ Later on, to save time and money, craftsmen were brought in from Basque country, and they developed this field of handicraft in Toledo to a degree that it became, to a certain extent, the pride of the city. At present, industrial mass production provides cheap souvenirs.

As in the case of the staff under discussion, ball-shaped handles are usually decorated with plant motifs inscribed within geometric sections [Fig. 2]. A stylised rosette at the top of the knob is usually inscribed within a round medallion, below which plant motifs are incorporated into triangular or semi-circular fields alternating with freely hanging twigs. There are also pieces decorated with portraits, ${ }^{9}$ fantastic animals, ${ }^{10}$ or the initials of the owner. ${ }^{11}$ Those produced in Toledo are

${ }^{8}$ I would like to thank Ms Ainhoa Lopez, a curator of Army Museum in Toledo, for this information.

${ }^{9}$ A ball-shaped cane handle decorated with a knight's head in a helmet at the top (cabeza de moro) inscribed within a circular medallion, made in Eibar in the early $20^{\text {th }}$ century, is part of the collection of the Khalili family: El Arte y Tradición de los Zuloaga. Damasquinado español de la colección Khalili, Oxford etc: The Khalili Family Trust, cop. 1997, p. 168, item 59; A spherical handle decorated with five portraits of knights in helmets inscribed within round medallions, dated to ca. 1880, was offered by the Patrick Gutknecht gallery in Geneva https://www.gutknecht-gallery.com/les_cannes/pommeau-spheriquetolede/, 24.07.2020. A similar handle, dated to the mid- $19^{\text {th }}$ century, was put up for a Koller auction in Geneva on 16 September 2016 (lot. no. 236) https://www. kollerauktionen.ch/en/100685-0017-----4014-TOLEDE-Travail-de-Tolede_mil-4014_431916.html?RecPos=69, 24.07.2020.

${ }^{10}$ A staff with a handle decorated with a figure of a dragon was on sale at the eBay auction portal https://www.ebay.com.sg/itm/BEST-GOLD-DAMASCENED-ON-IRON-GENTLEMANS-WALKING-STICK-CANE-DRAGONTOLEDO-SPAIN-/123425322041, 24.07.2020.

${ }^{11}$ A cane with a handle bearing the monogram LT, dated to the end of the $19^{\text {th }} \mathrm{c}$., was put on for CÔTE BASQUE ENCHERES auction in Saint Jean de 
sometimes signed with the name of the city inscribed within a ring around the shaft. ${ }^{12}$

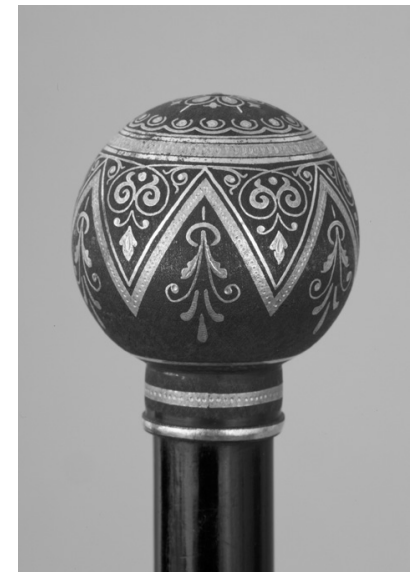

Fig. 2. Handle of a walking stick, Spain, Eibar or Toledo, $3^{\text {rd }}$ quarter of the $19^{\text {th }}$ century

Because the object discussed here is not signed, it is difficult to say for certain where it was made. The handle was probably manufactured in Eibar. ${ }^{13}$ Nevertheless, it seems that due to a certain universality of decorative motifs, Toledo cannot be excluded as the place of its origin. It should be noted here that it sometimes happens that although the handle was made by a Spanish craftsman, the whole cane might have been made outside of Spain. This suggestion is indirectly evidenced

Luz on 5 December 2015 (lot. no. 254) http://www.cotebasqueencheres.com/ lots/18838-canne-pommeau-rond-en-acier-damasquine-or-chiffre-lt-et-soul, 24.07.2020; Another piece, also embellished with initials, was offered by Galerie Fayet in Paris https://www.galerie-fayet.com/fr/cannes-de-collection/660-canneecaille-pommeau-tolede.html, 24.07.2020.

${ }^{12}$ A cane signed in this way was on offer in the Michel Weber Antiquités auction house in Paris http://www.weber-antiquites.com/produit/canne-tolede/, 24.07.2020.

${ }^{13}$ This centre was suggested as the place of origin by experts from the Army Museum in Toledo. 
by umbrella handles sold together with frame finishings by companies offering such accessories in other countries. A set like this made in Eibar at the beginning of the $20^{\text {th }}$ century, in a case bearing the name of a London shop selling fashionable women's accessories, is part of the Khalili family collection (Lavin, 1997: 167). The example given above is from the beginning of the $20^{\text {th }}$ century, but such cases may have happened earlier. Similar cane handles might have been sold individually, and later the shaft was added, selected in accordance with the future owner's taste and financial means. The shaft of the present object is made of ebony (or wood stained and varnished black with a view to imitating this exotic and expensive type of wood), so taking $19^{\text {th }}$-century etiquette into account, this cane was intended for evenings (to the opera or theatre), as during the day staffs made of light wood were used. ${ }^{14}$

The cane in question was part of the collection amassed by Stanisław Ursyn Rusiecki (1862-1944), educated in the field of history, art history, ethnography and archaeology, and donated to the Museum in 1935-1937. In accordance with a note written in the documentation of the donation, the cane had once belonged to Lucjan Siemieński (1807-1877), a poet and participant in the November Uprising of 1830-1831. ${ }^{15}$ Unfortunately, apart from a one-paragraph note, there is no information in the documents that would confirm or explain how Rusiecki came into possession of this object. Assuming this mention is true, it should be considered whether Siemieński's biography contains any information linking him with Spain. What we know is that in 1841-1842 he worked on an extensive selection of folk songs from all over the world. The "Piosennik ludów" series included only two parts devoted to Brittany and Scandinavian songs (Kiślak, 1997: 25). He was also interested in Spanish literature at that time, as we know from mentions in his correspondence. In letters to

${ }^{14}$ To be able to identify the genus of wood properly, it is necessary to conduct specialist dendrological analysis.

${ }^{15}$ The Archives of the National Museum in Krakow, The Chief Catalogue Department, File with documents concerning Stanisław Ursyn Rusiecki's gift, p. 785 . 
another Polish writer and poet, Seweryn Goszczyński (1801-1876), written in Strasburg in 1842, Siemieński mentions that he asked Leonard Rettel (1811-1885), the first Polish specialist in Spanish studies, to translate excerpts from Spanish romances, and at another time he asked Goszczyński to find some works on the poetry of the Spanish people in public libraries, because the treatises he had access to held no information about the mythological depictions (Małecki, 1977: 182, 183). Nevertheless, it is now difficult to say whether his interest in the literature of the region had anything to do with the acquisition of the walking stick in question. Nor do we know whether he bought it (or received it as a present) while staying abroad or in Krakow, where he lived from 1848. Regardless of where and how the cane was bought by Siemieński, it seems it can be dated to the third quarter of the $19^{\text {th }}$ century.

The other object of great interest is a cane which can be defined by its construction as both a walking stick and a dangerous, hidden weapon [Fig. 3]. ${ }^{16}$ This cane was probably a part of the military memorabilia collection amassed by Zygmunt Wierusz Kowalski (1846-1918). After Kowalski's death, his daughter Janina Kornecka initially deposited it and then donated it to the Museum in 1948 . At $94.0 \mathrm{~cm}$ in height, it consists of two parts joined together: the handle and the shaft [Fig. 4]. The handle, $20.7 \mathrm{~cm}$ long, in the shape of a cornet, empty and tapped inside, is topped with a flattened, heavy knob, $4.6 \mathrm{~cm}$ in diameter, cast in an iron alloy and decorated with an encrusted gold and silver Moorish motif. The cornet, finished with a convex ring at the bottom, is covered with a plaiting of thin straps of leather. Above the ring there is a brass wire hook for attaching a leather loop, now missing. The shaft is made of a straight branch, with snags visible in the upper part, at the bottom decorated with densely arranged horizontal, slightly wavy scars. In its upper part there is a steel blade in the form of a spike threaded at the bottom, $8.5 \mathrm{~cm}$ long, attached to the shaft with the use of a brass ferrule. The bottom end of the shaft has a brass ferrule, embellished with carved, geometric patterns and finished with a spike. The ferrule bears an inscription reading DUFOURG / A ST

16 The National Museum in Krakow, inventory number MNK IV-MO-1083. 
JNDE LUZ / 1881. The total length of the shaft including the blade and the bottom spike is $89.5 \mathrm{~cm}$.
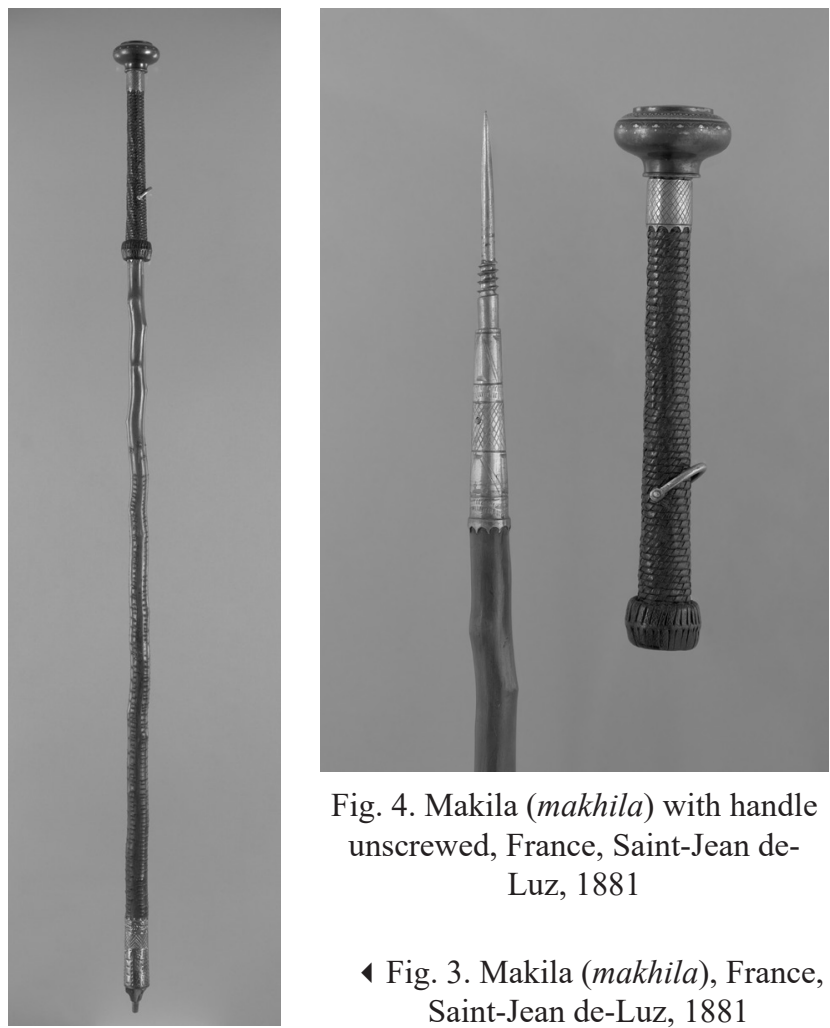

Fig. 4. Makila (makhila) with handle unscrewed, France, Saint-Jean deLuz, 1881

4 Fig. 3. Makila (makhila), France, Saint-Jean de-Luz, 1881

The inscription visible on the bottom ferrule suggests the staff was made in 1881 in Saint-Jean de-Luz, a town on the Atlantic coast in the Nouvelle-Aquitaine region, France, several kilometres from the border with Spain, a part of the Basque province of Labourd (Lapurdi). Both the construction and decoration signify that the cane is a Basque makila (makhila).

Basques are one of the oldest proto-Indo-European ethnic groups in the Iberian Peninsula, inhabiting a borderland area between Spain 
and France. In spite of not establishing their own country, they have maintained a separate language (Euskara, Euskera) and spiritual and material culture, and part of the area where they live enjoys certain political autonomy. They emphasise their ethnic and regional identity on various occasions. It is worth adding that until the beginning of the $20^{\text {th }}$ century they would wear traditional costumes not only during church and national celebrations. Along with the beret, the makila is characteristic of the Basque men's costume [Fig. 5].

The name makila (makhila) is probably derived from the Syrian language, in which the word makhel means fight. This language was used by the Phoenicians that the Iberians maintained contacts with. What should also be taken into account in the etymology of this word is the influence of the Etruscan language and Latin, in which the first letter in the word bakillu (Lat. bacillus, bacillum - little staff, stick) was replaced by the letter m (Dike, 1982: 243).

Makilas are usually made of the wood of medlar trees (Mespilus germanica L.) growing on the slopes of the Pyrenees, called mizpirandoa in the language of the Basques, which grow up to eight metres high under ideal conditions. Other genera

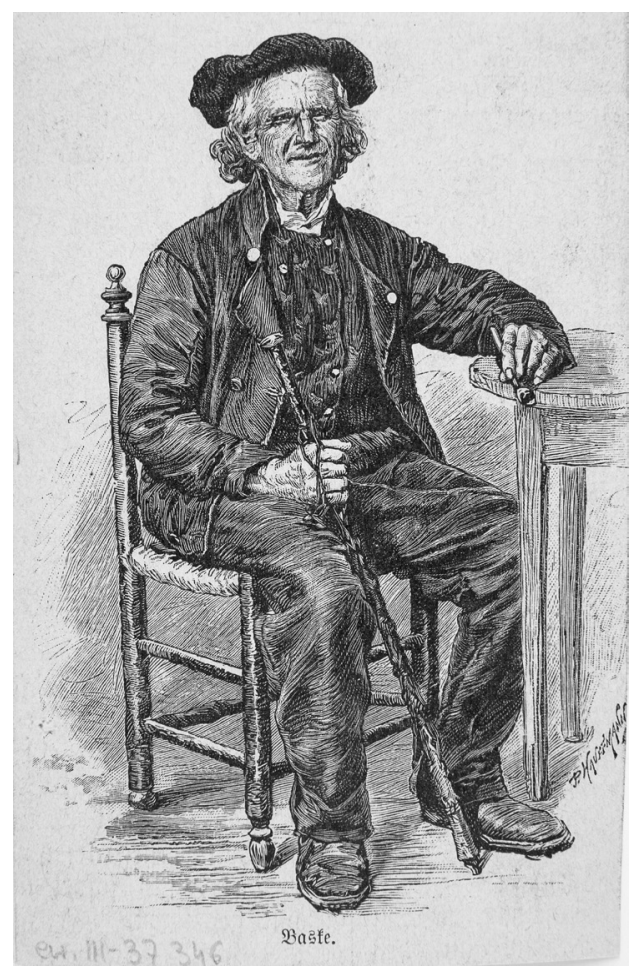

Fig. 5. Paul-Adolphe Kauffmann, Bask (excerpt from a German magazine), $2^{\text {nd }}$ half of the $19^{\text {th }}$ century 
of trees are sometimes used - aspen, maple, hazel (Cuzacq, 1950: 2), beech, juniper, holly, and gorse (Aguirre Sorondo, 1992: 225), but the medlar is considered to be the only one having all the required qualities, and a real makila must be made of it. A decorative pattern is obtained on the shaft by carving a design in the bark of a branch (of a living tree) of an appropriate diameter. The wood is sheltered from the rain and then, in late autumn when the wounds have healed and the design has been expanded, the branch is cut off and the wood undergoes further processing, the technology of which is kept secret by every maker and handed down from generation to generation. After the process of stripping off the bark, the branch is cut, straightened out and dried in the heat of a kiln, which requires expertise and experience, and then sometimes stained. Branches plunged in slaked lime assume a dark tinge reminiscent of the colour of walnut. A blade, approx. $20 \mathrm{~cm}$ long, is set in the upper part of the shaft and then a metal handle is attached to it. The handle was sometimes filled with lead, making this part of the stick very massive. The bottom ferrule could also be decorated, sometimes in silver repoussé. In this place the craftsmen would inscribe Basque sayings, sometimes the owner's name, or their own name and the date of making the cane. That being so, the inscription DUFOURG featured on the ferrule of the makila in question may refer to its owner or manufacturer. The ferrule ended with an iron spike in the form of a cross or a club (Cuzacq, 1950; Veyryn, 1955; Dike, 1982; Aguirre Sorondo, 1992; Broek, 2007).

The shape of the makila known at present dates back to the $19^{\text {th }}$ century, but it is possible to find mentions of it as early as in the $12^{\text {th }}$ century, in the sources where it is also referred to by different names (half-pike, spear or Basque club) (Dike, 1982: 243). Sticks similar to makilas can be seen in late-medieval depictions of pilgrims and saints. Pilgrims were not allowed to carry weapons, but along the way they were exposed to danger. A makila with a hidden blade used as a walking stick solved this problem. It seems significant that some centres where makilas have been produced to this day are situated on the way to Santiago de Compostela (Broek, 2007: 35). In 1950, Renè Cuzacq (1901-1977), a historian, secondary school teacher in 
Bayonne, regionalist and author of numerous works in the field of literature and folklore of western Gascony, mentioned spots along the Camino Baztanés route leading to Santiago de Compostela, including Espelette, Aïnhoa, Saint-Jean-Pied-de-Port, and Larressore, a small village in the region of Nouvelle-Aquitaine, as being locations where traditional methods of making makilas have been retained and cultivated (Cuzacq, 1950: 4). ${ }^{17}$ The Ainciart-Bergara atelier, a family workshop with a history going back to 1796 , has been operating to this day. ${ }^{18}$ In the village of Irun, situated in the region of the Basque Country in the north of Spain where Camino del Norte starts, the Iñaki Alberdi Sagardi workshop remains in operation, specialising in traditional makilas made to order (Aguirre Sorondo, 1992: 228). ${ }^{19}$

The makila was used not only for combat; it was, above all, a tool. The pointed bottom ferrule made it useful on the steep slopes of the Pyrenees. Shepherds used it to guide their flocks and defend against wolves. It was also used as an accessory in traditional dances and was given as an award in various contests. In the mid- $19^{\text {th }}$ century the village of Sare in the traditional Basque province of Labourd (currently in France, in the Nouvelle-Aquitaine region, on the border with Spain) held an annual contest in which improvisers and poets participated, and the best of them were awarded, along with 80 francs, "a silvery makila" (S.D., 1870: 456-457). At present the "Golden Makila" is awarded by the Latin American Film Festival in Biarritz (Aguirre Sorondo, 1992: 225). During World War I the makila enjoyed special popularity among English, Canadian and French officers, who used it to command their soldiers (Dike, 1982: 244). Returning to their homes, many of them took makilas with them as souvenirs. As a token of the Basques' gratitude, makilas were given to Marshals of France Ferdinand Foch and Philippe Pétain (Aguirre Sorondo, 1992: 225).

17 Other centres mentioned by this author: Hélette, Mauléon, Saint-Palais, Béarn w Navarrenx, Pau.

18 See https://makhila.com/en/ainciart-bergara/the-ainciart-bergara-family, 28.06.2019.

19 See also https://www.alberdimakila.com/en/alberdi-makila.html, 30.07.2020. 
Nowadays the makila is still presented to distinguished guests (Snyder, 2004: 218). These include Pope John Paul II, who received a makila made by Iñaki Alberdi during his visit to the Sanctuary of Loyola in 1992 (Aguirre Sorondo, 1992: 230). ${ }^{20}$ It is worth adding one more thing, although referring exclusively to the analogy of form, function, context and symbolism of the makila: it unavoidably brings to mind an attribute of the Tatra highlanders - the Podhale shepherd's axe, today being, like the makila, primarily a popular tourist souvenir or a gift to eminent guests.

To conclude this paper, the main aim of which is to present and bring two artefacts in the collection of the National Museum in Krakow into wider scholarly and research circulation, it is worth noting that like other accessories, canes provide a good deal of information about their owners - apart from their aesthetic tastes, walking sticks also signified their social rank and wealth, and not infrequently their political sympathies. The staffs described in this article represent two categories, the first being an elegant clothing accessory carried by a man who took care of his appearance. Although its handle was made in Spain, as a whole the cane might have been made and used outside its borders. The other of the staffs, one linked more with the local folklore, provides information about the place where it was made. It appears it was made for a specific recipient from that region. Although the place where the makila was made belongs to France from an administrative point of view, it is closely connected with the culture of Basques, whose country is situated in the north of Spain. Both pieces are examples of artefacts sought after by collectors of walking sticks. By the way, it is worth adding that the collection of "curious staffs" amassed by the Polish writer and painter Stanisław Ignacy Witkiewicz (1885-1939) also included a Basque cane with an inscription and a dagger (Sztaba, 1982: 273).

Translated by Marta Herudzińska-Oświecimska

${ }^{20}$ A picture of Pope John Paul II holding the makila can be seen at https:// www.alberdimakila.com/ca/makila-personajes-medios.html, 30.07.2020. 


\section{Bibliography}

AGUIRRE SORONDO, A. (1992), "Palos, bastones y makilas", Cuadernos de Etnología y Etnografía de Navarra, Año XXIV, no. 60, pp. 202-235.

BOBROW, R. (2008), "Pamiątki władz Warszawy w Muzeum Narodowym w Warszawie. Losy i inicjatywy muzealne”, Rocznik Warszawski, vol. XXXVI, Warszawa, pp. 205-216.

BOOTHROYD, A.E. (1973), Fascinating walking stick, London-New York.

BROEK, G. J. van den, (2007), The return of the cane. A natural history of the walking stick, Utrechvol.

BRÜCKNER, A. (1939), Encyklopedia staropolska, vol. 1, Kraków.

BUJANOVICS, E. (2011), Sétabot, Pauker Holding Kft.

CUZACQ, R. (1950), Makhila et Aghulade [,,sic" pour Agulhade], I, (Extrait de "Pyrénées" no 3), Pau.

DIKE, C. (1982), Les cannes a système. Un monde fabuleux et méconnu, Genève.

DIKE, C., BEZZAZ, G. (1988), La canne. Object d'art, Paris-Genève.

GLOGER, Z. (1902), Encyklopedia Staro-polska Ilustrowana, vol. III, Warszawa.

GUTKOWSKA-RYCHLEWSKA, M. (1968), Historia ubiorów, WrocławWarszawa-Kraków.

KIŚLAK, E. (1996-1997) “Lucjan Hipolit Siemieński (Siemiński)”, in: Polski Stownik Biograficzny, vol. XXXVII, pp. 23-28.

KLEVER, U. (1996), Walkingsticks. Accessory, tool and symbol, Shiffer Publishing Ltd.

LAVIN, J. D. (1997), El Arte y Tradición de los Zuloaga. Damasquinado español de la colección Khalili, Oxford etc. The Khalili Famili Trust, cop.

MAŁECKI, M. ed. (1977), Lucjan Siemieński. Listy do różnych adresatów z lat 1827-1843, Archiwum Literackie XXI, Miscellanea z okresu Romantyzmu, 3, Wrocław-Warszawa-Kraków-Gdańsk.

MORRIS LESTER, K. M., OERKE, B. V., (1940), An illustrated history of those frills and furbelows of Fashion which have come to be known as: Accessories of Dress, Peoria Illinois.

ORGELBRAND, S. (1864), Encyklopedyja powszechna, vol. 16, Warszawa. 
[S. D.], (1870), "Kronika paryzka literacka, naukowa, artystyczna", in: Biblioteka Warszawska. Pismo poświęcone naukom, sztukom i przemysłowi, vol. 2, Warszawa.

SIEDLECKA, W. (1964), Techniki zdobnicze metali, Wrocław.

Słownik terminologiczny sztuk pięknych, (1997), Warszawa.

SNYDER, J. B. (2004), Canes \& walking sticks. A stroll through time and place, Shiffer Publishing Ltd.

SZTABA, W. (1982), Gra ze sztuka. O twórczości Stanisława Ignacego Witkiewicza, Kraków.

VEYRIN, P. (1955), Les Basques De Labourd, de Soule et de Basse Navarre. Leur histoire et leurs traditions, Grenoble.

Wielka Encyklopedya Powszechna Ilustrowana, (1908) Serya I, vol. XLI, Warszawa.

ZWOLIŃSKA, K., MALICKI, Z. (1975), Mały słownik terminów plastycznych, Warszawa.

\section{List of illustrations}

Fig. 1. Walking cane, Spain, Eibar or Toledo, $3^{\text {rd }}$ quarter of the $19^{\text {th }}$ century. The National Museum in Krakow, inv. No. MNK IV-MO-1071. Photo: The Photography Studio of the National Museum in Krakow.

Fig. 2. Handle of a walking stick, Spain, Eibar or Toledo, $3^{\text {rd }}$ quarter of the $19^{\text {th }}$ century. The National Museum in Krakow, inv. No. MNK IV-MO-1071. Photo: The Photography Studio of the National Museum in Krakow.

Fig. 3. Makila (makhila), France, Saint-Jean de-Luz, 1881. The National Museum in Krakow, inv. No. MNK IV-MO-1083. Photo: The Photography Studio of the National Museum in Krakow.

Fig. 4. Makila (makhila) with handle unscrewed, France, Saint-Jean de-Luz, 1881. The National Museum in Krakow, inv. No. MNK IV-MO-1083. Photo: The Photography Studio of the National Museum in Krakow.

Fig. 5. Paul-Adolphe Kauffmann, Bask (excerpt from a German magazine), $2^{\text {nd }}$ half of the $19^{\text {th }}$ century. Woodcuvol. The National Museum in Krakow, inv. No. MNK III-ryc-39524. Photo: The Photography Studio of the National Museum in Krakow. 